\title{
The Politics of Paradox: Metaphysics Beyond "Political Ontology"
}

\section{Adrian Pabst}

\section{Introduction}

Much of nineteenth- and twentieth-century philosophy proclaimed the end the metaphysics and the death of God. The German, French, and English strands of the Enlightenment were united in their suspicion of metaphysical theism. Figures as diverse as Comte, Marx, Spencer, Nietzsche, and Russell defended the absolute autonomy of atheist reason against religious faith. Following the rise of partisan ideologies that terrorized the West from 1789 to 1989, the downfall of the Soviet empire appeared to herald the "end of history" and a global convergence toward liberal market democracy. Ideas of freedom and justice would henceforth be confined to the immanent space of secular politics and stripped of all references to the transcendent, supernatural Good. ${ }^{1}$ Thus, the advent of post-ideological politics seemed to be broadly in line with the anti-metaphysical outlook of postmodern philosophy.

But as we now know, the end of history never began. 1989 was not so much the victory of democratic capitalism over totalitarian communism as the uprising of civil society and the Church against authoritarian regimes and state-orchestrated atheism. ${ }^{2}$ In the West and elsewhere, the 1990s witnessed the triumph of neo-liberal ideology masquerading as pragmatic

1. Francis Fukuyama, "The End of History?" The National Interest 16 (1989): 3-18; John Rawls, "Justice as Fairness: Political not Metaphysical," Philosophy and Public Affairs 14, no. 3 (1985): 223-51.

2. Ernest Gellner, Conditions of Liberty: Civil Society and Its Rivals (London: Allen Lane, 1994); Maurice Glasman, Unnecessary Suffering: Managing Market Utopia (London: Verso, 1996), pp. 86-97. 
centrism - a "third way" beyond left and right, to which there was seemingly no alternative. ${ }^{3}$ 9/11 marked the displacement of secular terror by religious terror and the clash of fanatical faiths that are secretly collusive. ${ }^{4}$ Crucially, the return of religion in international relations has coincided not just with the "theological turn" of both French phenomenology and "Anglo-Saxon" philosophy. ${ }^{5}$ Of equal, if not greater, importance is the revival of metaphysics and virtue ethics across the continental/analytic divide. ${ }^{6}$ So what we are seeing is not the contours of politics and ethics beyond metaphysics but rather the revival of metaphysical ideas that are variously more theological or more secular.

Why the resurgence of metaphysics? Is not metaphysics wedded to a foundationalist conception of being and to transhistorical, objectively fixed notions of truth or meaning that provide the transcendent grounding of modern political thought? Does not the demise of modernity finally liberate subjectivity from the illusion of a life invested with sacred significance and governed by supernaturally determined ethical imperatives? Instead of equating the modern with the metaphysical, this essay contends that it was the late medieval exit from metaphysics that brought about the modern "political ontology" that is now in crisis. As such, postmodern philosophers from Nietzsche to Heidegger and from Jacques Derrida to Jean-Luc Marion are wrong to dismiss the whole Western tradition of metaphysics since Plato as onto-theological. The metaphysical politics that the essay seeks to retrieve overcomes the modern logic of dualism and

3. Anthony Giddens, Beyond Left and Right (Cambridge: Polity, 1994); Anthony Giddens, The Third Way (Cambridge: Polity, 1998).

4. Adrian Pabst, "Unholy War and Just Peace: Religious Alternatives to Secular Warfare," Politics and Religion, 3, no. 2 (2009): 209-32.

5. Dominique Janicaud, Le tournant théologique de la phénoménologie française (Paris: Ed. de 1'Eclat, 1991); Craig Paterson and Matthew S. Pugh, eds., Analytical Thomism: Traditions in Dialogue (Aldershot: Ashgate, 2006).

6. Emmanuel Lévinas, Autrement qu'être ou Au-delà de l'essence (Paris: Le Livre de Poche, 1974); Alasdair MacIntyre, After Virtue, 2nd ed. (London: Duckworth, 1985); Alain Badiou, L'être et l'événement (Paris: Seuil, 1988); Alain Badiou, Abrégé de métapolitique (Paris: Seuil, 1998); Alain Badiou, Logiques des mondes: L'être et l'événement 2 (Paris: Seuil, 2006); Ray Brassier, Nihil Unbound: Extinction and Enlightenment (London: Palgrave Macmillan, 2007). Cf. John Milbank, "Only Theology Saves Metaphysics," in Peter M. Candler Jr. and Conor Cunningham, eds., Belief and Metaphysics (London: SCM, 2007), pp. 452-500; John Milbank, "The Return of Metaphysics in the 21st Century," in Philosophy: A Theological Critique (Oxford: Wiley-Blackwell, 2013), ch. 1. 
the postmodern dialectics of difference in the direction of the non-modern logic of paradox that offers the possibility of an alternative modernity.

The first part shows how modern "political ontology" originates with the late medieval reconception of metaphysics as onto-theology. Duns Scotus's transcendental science of onto-theology is correlated with Ockham's nominalist-voluntarist account of power and Machiavelli's secular science of politics. The second part suggests that liberalism combines transcendentalism with positivism and underpins the politics of left versus right, which has been dominant since the secular settlement of the French Revolution. The third part contrasts the dualism of modern "political ontology" with the paradox of metaphysical politics.

\section{Modern Political Ontology in Question}

Broadly speaking, modernity has been equated with variants of metaphysics - including Descartes' first philosophy, Kant's transcendental idealism, and Hegel's panlogism. Similarly, postmodernity is associated with the attempt to overcome the metaphysical in one of two directions: either various phenomenological accounts of pure appearing outside being or else analytic philosophies of language and logic prior to being. Parallel considerations apply to politics and ethics. For the moderns, the representation of subjects as formal bearers of equal yet abstract, individual rights warranted a shift in sovereignty from the autonomy of corporate groups or associations to the collective power of the city (Descartes), the state (Hegel), or the liberal cosmospolis (Kant) over the individual. ${ }^{7}$ Against modern dualism that collapses back into monism, the postmodern celebration of difference promised the sort of emancipation that the Renaissance and the Enlightenment purported to provide but failed to deliver.

But if, as the French philosopher of science Bruno Latour has argued, "we have never been modern" because there was never any absolute, irreversible break in history that gave rise to a coherent system of ideas and institutions that we commonly call "modernity," perhaps it is then also the case that we have been never been postmodern because postmodernity retrieves and extends certain modern ideas. Philosophically and politically, those ideas can be traced to the late medieval shift from the

7. Adrian Pabst, "Modern Sovereignty in Question: Theology, Democracy and Capitalism," Modern Theology 26, no. 4 (2010): 570-602.

8. Bruno Latour, Nous n'avons jamais été modernes: essai d'anthropologie symétrique (Paris: La Découverte, 1991). 
metaphysics of participation and the analogy of being to the ontology (or later epistemology) of representation and the univocity of being. ${ }^{9}$ I shall return to the nature and importance of this shift presently.

For now, a brief point needs to be made about the postmodern appeal to univocal being and the immanent. Whether the quasi-metaphysical Marxism of Gilles Deleuze or the apparently pluralist liberalism of John Rawls, both these thinkers invoke in different ways the reign of immanence to defend a kind of political pluralism that is variously more revolutionary or more conformist. ${ }^{10}$ Likewise, the late medieval collapse of divine being and created being into a single, univocal singularity of being that is transcendentally prior even all actual finite beings becomes the ontological event of the virtual in Deleuze and Badiou. Beyond both actuality and possibility, the virtual either enfolds the difference of the many within the univocal being of the one (Deleuze) or else the irreducible infinity of the multiple that nevertheless manifest the universal (Badiou). ${ }^{11}$ Catherine Pickstock's characterization of our contemporary condition as "postmodern scholasticism" and as a certain "modern Middle Age" is surely correct. ${ }^{12}$ So if "postmodernity" is in the end a radicalization of certain modern developments rather than a new phase of history, then it is also the case that the modern coincides with the onto-theological science of transcendental ontology and not after all with metaphysics.

To understand the significance of this difference for political philosophy, a revisionist genealogy is needed. Pace Heidegger and Derrida, it is wrong to claim that the whole of Western metaphysics since Plato has been onto-theological and logocentric. Nor is it correct to suggest that Kant's critical turn liberated philosophy from theistic metaphysics and secured

9. Olivier Boulnois, Être et représentation. Une généalogie de la métaphysique moderne à l'époque de Duns Scot (XIIIe-XIVe siècle) (Paris: P.U.F., 1999). Cf. Catherine Pickstock, "Modernity and Scholasticism: A Critique of Recent Invocations of Univocity," Antonianum 78 (2003): 3-46; Adrian Pabst, Metaphysics: The Creation of Hierarchy (Grand Rapids, MI: W. B. Eerdmans, 2012), pp. 272-382.

10. Gilles Deleuze, Différence et répétition (Paris: P.U.F., 1968); Gilles Deleuze and Félix Guattari, Capitalisme et schizophrénie 1: L'anti-Edipe (Paris: Minuit, 1972) and Capitalisme et schizophrénie 2: mille plateaux (Paris: Minuit, 1980); John Rawls, Political Liberalism (New York: Columbia UP, 1993).

11. In addition to Alain Badiou's duology L'être et l'événement, see his Court traité d'ontologie transitoire (Paris: Seuil, 1988).

12. Catherine Pickstock, "Postmodern Scholasticism: Critique of Postmodern Univocity," Telos 126 (2003): 3-24. 
the autonomy of the subject. Much rather, the late medieval shift from metaphysical participation and analogical being to ontological-epistemological representation and univocal being introduced a series of concepts that remain central to modern and postmodern politics. In what follows, the focus will be on three related notions: the primacy of the possible over the actual (possibilism); univocal being and the autonomy of philosophy from theology (transcendentalism); absolute power and the autonomy of politics from metaphysics (absolutism).

First of all, beginning with Avicenna and influential Latin theologians such as Gilbert Porreta in the eleventh century, the notion of being (ens) gradually changed from that which is by participating in the transcendent source of being itself to a transcendental category that includes all beings, divine or created. ${ }^{13}$ Being so configured is transcendentally prior to actuality and coextensive with all the conditions of possibility for the instantiation of finite beings by the infinite cause of being. For Avicenna as for John Duns Scotus, the necessity of the possible takes precedence over the contingency of the actual. William of Ockham's work radicalizes the primacy of the possible over the actual by claiming that possibility precedes both actuality and intelligibility. As such, the contingent no longer reveals its origin in the pure act of God but is instead grounded in the transcendental realm of the possible that is beyond the logical and the actual. Ockham writes that "possible being is something a creature has of itself [... and] a creature is possible, not because anything pertains to it, but because it can exist in reality." ${ }^{14}$ Coupled with his nominalism (denying the real presence of universals in things), Ockham's ontology drains actually existing beings of any relation to their divine source: "divine actuality disappears behind the infinite variety of what is possible." 15 Thus, actual being loses ontological integrity and reflects nothing but the potentia absoluta of divine volition, which is central to his account of political power. By elevating the possible over the actual, Scotus and Ockham inaugurated modern modal metaphysics: "until the early fourteenth century

13. Eric Alliez, Les temps capitaux, vol. 1, Récits de la conquête du temps (Paris: Cerf, 1991), pp. 269-322.

14. William of Ockham, I Sent., d. 43, q. 2, in Opera Philosophica et Theologica, ed. G. I. Etzekorn and F. E. Kelley (St. Bonaventure, NY: St. Bonaventure UP, 1979), $4: 640-50$.

15. Harry R. Klocker, William of Ockham and the Divine Freedom (Milwaukee: Marquette UP, 1992), p. 114. 
possibilities were treated as having a foundation in God; in the modern theory they were dissociated from this ontological backing." 16

Second, Scotus's ontology marks a decisive break with the Thomist metaphysics of participation and analogical being. As a transcendental category that encompasses both finite and infinite being, ens is no longer distributed analogically among finite beings but instead applies univocally to both God and creation. ${ }^{17}$ Thus Scotus rejected (what was later accurately termed) Aquinas's analogia entis in favor of univocal being. If ens is univocal, then it represents at once the most general and the highest form of being. That is why Olivier Boulnois is right to argue that the conception of metaphysics as onto-theology begins with Scotus, not with Aristotle or Aquinas. ${ }^{18}$ By redefining the object as univocal being, the onto-theological turn of metaphysics brackets the question of God and inverts the medieval pre-eminence of theology over philosophy, which was common to Plato and Aristotle. In this manner, onto-theology foreshadows the secular autonomy of reason from faith.

Like the other shifts discussed in this section, the emergence of transcendentalism is complex and would require a longer exposition that is beyond the scope of this essay. However, we know that it was Francisco Suárez who in the late sixteenth century posited the priority of metaphysics as the science of general being over theology as the science of revelation. Linked to this is his separation of "pure nature" from the supernatural and other dualistic oppositions such as faith versus reason or the body politic versus the corpus mysticum of the Church. ${ }^{19}$ Following Scotus and Suárez, the German thinker Johannes Clauberg or Clauvergius (1622-65)

16. Lilli Alanen and Simo Knuuttila, "The Foundations of Modality and Conceivability in Descartes and His Predecessors," in Simo Knuuttila, ed., Modern Modalities: Studies of the History of Modal Theories from Medieval Nominalism to Logical Positivism (Dordrecht: Kluwer, 1988), pp. 1-69; here, p. 41.

17. Ludwig Honnefelder, Ens inquantum ens: Der Begriff des Seiendes als solchen als Gegenstand der Metaphysik nach der Lehre des Johannes Duns Scotus (Münster: Aschendorff, 1979); Ludwig Honnefelder, Scientia transcendens: Die formale Bestimmung der Seiendheit und Realität in der Metaphysik des Mittelalters und der Neuzeit (Duns Scot, Suarez, Kant, Pierce) (Hamburg: Meiner, 1990).

18. Olivier Boulnois, "Analogie et univocité selon Duns Scot: la double destruction," Les Études Philosophiques 3 (1989): 347-69; Olivier Boulnois, "Quand commence l'ontothéologie? Aristote, Thomas d'Aquin et Duns Scot," Revue Thomiste 95 (1995): 85-108.

19. John Montag S.J., "Revelation: The False Legacy of Suárez," in John Milbank et al., eds., Radical Orthodoxy: A New Theology (London: Routledge, 1998), pp. 38-63. Cf. Pabst, Metaphysics, pp. 308-40. 
replaced the term "metaphysics" with "ontosophia" or "ontology" in order to describe the science of being qua being (ens inquantum ens). ${ }^{20}$ Through the work of Christian Wolff, Kant inherits the twin strands of transcendentalism and possibilism that underpin his focus on the conditions of possibility. Even if the term metaphysics does not fall into desuetude, it is nevertheless the case that its meaning has already shifted from participation in the transcendent being of God to the representation of transcendental being itself.

Third, ontological transcendentalism is correlated with political absolutism. Here the crucial nexus is between Ockham's nominalist-voluntarist theology and Machiavelli's new science of politics. According to nominalist ontology, universals only exist in the mind and are not present in things, which separates the transcendent source of being from the immanent world. Paradoxically, that move was anticipated by Scotus's univocal collapse of divine and created being into transcendental ens and the concomitant bracketing of God from ontology. The voluntarist subordination of God's intellect to the power of volition privileges divine intervention in the world based on potentia Dei absoluta at the expense of grace and wisdom. The combined effect of Ockham's nominalist and voluntarist theology is to elevate the singular over the universal and to sunder the earthly dominium from the heavenly city of God. This autonomy foreshadows Suárez's later separation of nature from the supernatural and provides the foundation for state supremacy vis-à-vis the Church and all other institutions within the temporal-spatial realm of the saeculum. As Janet Coleman suggests, the consequence of separating politics from theology is that

secular politics not only has its own process of self-correction, but that it is independent of ecclesial power.... Because the temporal sphere is imperfect, he [Ockham] argued that secular sovereignty, once established, could be legitimate even when 'absolute', in that there need not be regular participation of the people in government, nor need there be institutions to restrain the power of kings. ${ }^{21}$

20. Johannes Clauberg, Elementa philosophiae sive ontosophiae (Groningen: Joannis Nicolai, 1647). See Etienne Gilson, L'être et l'essence, 2nd ed. (Paris: Vrin, 1972), pp. 144-86; Jean-François Courtine, Suarez et le système de la métaphysique (Paris: P.U.F., 1990), pp. 246-92, 436-57.

21. Janet Coleman, “Ockham's Right Reason and the Genesis of the Political as 'Absolutist,"” History of Political Thought 20 (1999): 35-64; here, pp. 48, 50. 
Thus, Ockham's account of unconstricted secular sovereignty foregrounds the doctrine of the divine right of kings that underpins modern political absolutism. ${ }^{22}$

Machiavelli fuses the late medieval nominalist-voluntarist account of autonomous secular authority with a neo-pagan conception of power as virtù (or heroic agonism). He radicalizes the early modern redefinition of dominium as power, private property, individual rights, and absolute sovereignty $^{23}$ by divorcing the exercise of legitimate authority from notions of moral goodness. In this way, his account inverts the primacy of the good over evil (defined by St. Augustine as privatio boni) and defends a political anthropology that is predicated on violent conflict. This inversion goes back to Ockham's nominalist erasure of universal goodness from particular beings and anticipates the idea of a violent state of nature in the modern tradition of the social contract from Hobbes to Kant. Contrary to the metaphysics of participation that views the civitas terrena as ordered toward the hierarchical ends of the civitas Dei in which it partakes, transcendental "political ontology" equates the kingdom and city-republic with a competition for survival and power.

In The Prince (especially chapter IX), it is the use of fear and force that ultimately regulates political and civic life, not the pursuit of peace or virtuous practice. ${ }^{24}$ Connected with this is the appeal to myth of fortuna, an imagined existential threat to the political order that demands a violent response- based on redefining virtue in terms of the neo-pagan heroism that invests the leader with a secular sacrality. ${ }^{25}$ Here it is instructive to consider Suárez who opposes the divine right of kings in the name of popular sovereignty but radicalizes Ockham's argument that the unilateral transfer of power from the people to the monarch is necessarily irrevocable. In contrast to Aquinas's distinction between the church as corpus mysticum and the state as "body politic," Suárez's conception of the population as a

22. John Neville Figgis, The Theory of the Divine Right of Kings (Cambridge: Cambridge UP, 1896).

23. John Milbank, Theology and Social Theory: Beyond Secular Reason, 2nd ed. (Oxford: Wiley-Blackwell, 2006), pp. 7-25.

24. Pierre Manent, Histoire intellectuelle du libéralisme: dix leçons (Paris: CalmannLévy, 1987), pp. 31-50; J. G. A. Pocock, The Machiavellian Moment: Florentine Political Thought and the Atlantic Republican Tradition, rev. ed. (Princeton, NJ: Princeton UP, 2003), pp. 156-82.

25. Niccolò Machiavelli, The Prince, ch. 25, in The Chief Works and Others, trans. Allan Gilbert (Durham, NC: Duke UP, 1965), vol. 1, esp. pp. 90-92. 
"single mystical body" replaces the patristic and medieval primacy of the ecclesial community over the state with the early modern supremacy of the state over the people. Just as Scotus and Ockham secularize the political order, so Machiavelli and Suárez sacralize state power.

Divine will and potentia Dei absoluta are in some sense reflected in the monarch's will-to-power. Arguably, one can speak of political absolutism because power is now neither seen as a gift of divine grace that requires righteous rule nor constrained by substantive transcendent telos - whether an impersonal cosmic force such as Plato's Good and Aristotle's Prime Mover or the personal Creator God of the Judeo-Christian tradition. Machiavelli's purported realism turns out to be an extension of Ockham's nominalism and voluntarism that builds on Scotus's ontology of representation.

Taken together, the triple currents of possibilism, transcendentalism, and absolutism flow from Avicenna, Scotus, and Ockham through Machiavelli through Suárez to Hobbes, Locke, and Kant. The collective dimension of sovereign authority is reduced to an individualist mode of power, while at the same time the citizens and corporate groups that compose the common polity are subsumed under a collectivity whose continued assent is no longer required. Popular sovereignty is entirely compatible with the absolute, executive power of the sovereign. Authoritarian democracy - whether in its republican (Machiavelli) or its monarchical guise (Suárez) - is not so much a contradiction or an oxymoron as a paradox that links modern absolutism to modern liberalism. ${ }^{26}$ Here one can already see the dialectic between the "one" and the "many" that is coextensive with the nominalist poles of left versus right, which govern both modern and postmodern politics - as the following section argues.

\section{Liberalism and the (Post-)Modern Politics of Left versus Right}

Philosophically and politically, there are three fundamental continuities from the late Middle Ages through modernity to our late (or post-)modern era. First of all, a twin accentuation on "the rule of the one" and "the rule of the many." The former is the sovereign center that is either more autocratic or more plutocratic - or indeed both. The latter is the sovereign people who are either in contracted dispersion or in collective unity. The "one" and "the many" are dialectically related and collude at the expense of the

26. Cf. Milbank, Theology and Social Theory, p. 14. 
mediating role of "the few," a notion that for Plato, Aristotle, and Christian Neo-Platonists refers to virtuous elites who uphold principles and practices of reciprocity and mutuality (e.g., Politics II, 2, 1261a30-35). ${ }^{27}$

Second, linked to this configuration is the power of the central state and the free market. Both are constructed based on the myth of human artifice (such as the social contract) that brings about a peaceful natural order (beyond the violent state of nature).$^{28}$ As such, state and market converge and subsume the intermediary institutions of local and global civil society under the hegemony of the international system of nation-states. The logic of abstraction that governs both bureaucratic control and commercial exchange does not just commodify labor and social relations but also subordinates the sanctity of life and land to the secular sacrality of the market-state. $^{29}$

Third, the political "right" and the political "left" have defined themselves variously either in terms of the "one" and the "many" or in terms of the market and the state or in terms of the economic and the political — or indeed all at once. All these poles are dialectically positioned and converge around a shared liberalism that fuses Machiavelli's "new science of politics" with the eighteenth-century invention of political economy, as Michel Foucault has documented. ${ }^{30}$

Crucially, these three binary relations of the "one" versus the "many," the market versus the state and the "right" versus the "left" are all rational, spatial constructs that combine ontological nominalism with political voluntarism, as André de Muralt's genealogical account shows. ${ }^{31}$ Taken together, these binary relations have redefined the nature and reality of civil society that in principle enjoys primacy over states and markets and

27. Aristotle develops this line of argument in the direction of a constitutional system of "mixed government" that combines "monarchical," "aristocratic," and "democratic" elements, which blend hierarchy with equality (Politics IV, 1288b10-1301a15). Cf. Michel Foucault, "Omnes et singulatim: Towards a Criticism of Political Reason (1979)," in The Tanner Lectures on Human Values, ed. S. M. McMurrin (Cambridge: Cambridge UP, 1981), 2:225-54.

28. Bernard E. Harcourt, The Illusion of Free Markets: Punishment and the Myth of Natural Order (Cambridge, MA: Harvard UP, 2011).

29. Karl Polanyi, The Great Transformation: The Political and Economic Origins of Our Time (Boston: Beacon Press, 1944).

30. Michel Foucault, Naissance de la biopolitique: cours au Collège de France, 1978-1979 (Paris: Seuil, 2004).

31. André de Muralt, L'unité de la philosophie politique: De Scot, Occam et Suarez au libéralisme contemporain (Paris: Vrin, 2002). 
embeds both abstract rights and formal contracts in real relations. Indeed, modern political ontology combines "the sovereign one" associated with the right and "the sovereign many" linked with the left that are variously more authoritarian-statist or more market-fundamentalist - or again both at once.

With this nominalist space, the primary real relations among personswho cooperate for both self-interest and the common, public good-are superseded by abstract, formal links consisting of either constitutionallegal rights or economic-contractual ties. Those links favor activities for either commercial-market or state-administrative purposes and therefore are to the detriment of practices that are not purely instrumental but might pursue wider, social purposes. As a result, modern politics is little more than a social contract between the general will represented by the state (e.g., Hobbes, Kant, Hegel, and, more recently, Norberto Bobbio), on the one hand, and the personal will asserted through inalienable individual rights (e.g., Bodin, Locke, J. S. Mill, and, more recently, John Rawls), on the other hand. The logic of representation is the same nominalistvoluntarist logic of transcendentalism and possibilism that underpins both modern absolutism and modern liberalism.

The extension of popular democracy and human rights since 1848 has in some measure curtailed the arbitrary power of the "sovereign one" to the benefit of the "sovereign many." However, democratization and individual rights have not just weakened the participation of the "few" but also subverted the ideal of representation. Democratic rule, especially in its secular liberal guise, views as legitimate only a vacuous generality such as abstract values that are drained of any substantive universal telos embodied in particular virtues. As such, democracy privileges the spectacle of representing the general will over and above the concerns of the represented people. Tocqueville's observation that freedom of expression is perfectly compatible with the tyranny of mass general opinion could hardly be more prescient in today's "society of spectacle" (Guy Debord).

Liberalism has not only extended the three currents of possibilism, transcendentalism, and absolutism but also fused them with the new doctrine of positivism. The liberal belief in boundless, linear progress was in large part founded on the scientific positivism of Comte and Spencer and shaped both Marxism and Fascism/Nazism. ${ }^{32}$ Indeed, the twentieth century saw

32. Andrew Wernick, Auguste Comte and the Religion of Humanity: The Post-theistic Program of French Social Theory (Cambridge: Cambridge UP, 2001); John Gray, Black 
an apparent bifurcation between statisms on the far left or the far right, on the one hand, and economic-social ultra-liberalism, on the other hand. But both were grounded in the legal-positivist equation of "is" with "ought" that is nominalist-voluntarist. Moreover, both at the end of the nineteenth century and in the twilight of the twentieth century, the collusion of the strong state with the free market has produced "a hidden mutual complicity and reinforcement between the voluntarism of the absolute state and the voluntarism of the self-governing, negatively choosing individual." ${ }^{\prime 33}$ Connected with this is the claim that only liberalism provides pluralism and diversity of choice - a "possibilist" utopia that Michael Oakeshott poignantly called "the blank sheet of infinite possibility." 34 Yet at the same time, the liberal settlement is really an imposed, even coercive, consensus to ensure that no choice other than liberalism can ever be effectively exercised. As such, the notion of illiberal liberalism is increasingly warranted.

Much of postmodern thought seeks to overcome the transcendental foundationalism and liberal absolutism that characterize modern "political ontology." However, the shift in emphasis away from modern dialectics toward postmodern difference (however spelled) merely repeats and even reinforces the pan-modern logic of dualism. By enshrining difference as the new "absolute," much of postmodern philosophy and politics brackets the mediating relation between the unity of the "sovereign one" and the diversity of the "sovereign many." As such, the postmodern reign of difference collapses into monism - whether a monism of the "one," such as the Spinozism of Deleuze, or a monism of the "many," like the rule of the multiple according to Hardt and Negri. ${ }^{35}$ The trouble is that postmodern monism so configured risks lapsing back into absolutism or else descending into nihilism. In either case, the securing of difference is of a piece with the celebration of neo-pagan agon that is variously more tragic or more heroic. Thus, postmodern difference is ultimately reducible to modern dialectics, and both are part of the logic of dualism that privileges nominal connections grounded in the will- the power of the one substance or the multiple multitude to "will" themselves into actuality.

Mass: Apocalyptic Religion and the Death of Utopia (London: Allen Lane, 2007).

33. John Milbank, "The Real Third Way," in Adrian Pabst, ed., The Crisis of Global Capitalism (Eugene, OR: Wipf\&Stock, 2011), pp. 27-70.

34. Michael Oakeshott, Rationalism in Politics and Other Essays (Indianapolis: Liberty Fund, 1991), p. 9.

35. Michael Hardt and Antonio Negri, Multitude: War and Democracy in the Age of Empire (London: Penguin, 2004). 
One alternative is to reach beyond monism in the direction of a nonabsolutist and non-nihilist universal that transcends the violent agon of difference. Badiou's work, which is based on Cantor's theory of "infinite infinites," is a case in point. Badiou's ontology consists in an infinite set of multiples that can be further deconstructed into infinite subsets, which are compatible with the pure event of universal singularity beyond the ontologic of representation. ${ }^{36}$ But linked to the self-instigating advent of pure event is for Badiou a Maoist advocacy of militant anti-capitalism outside of parliamentary politics and provisional revolutionary state terror, which is part of a naturalistic ideology that underpins both state collectivism and the uprising of the masses. What Badiou's speculative naturalism has in common with the nominalist-voluntarist logic of modern ontology is to reject the analogy of being and bracket transcendence out of the picture. As a result, immanent beings lack real ties with one another, and there is nothing to mediate between the radical singularity of each being. Politics oscillates between a shared struggle against free-market homogenization, on the one hand, and the uniformizing forces of statism, on the other hand-without a transcendent outlook that can bind together singulars and direct them to their common source. For this reason, Badiou's apparent alternative fails to overcome the late medieval dualism of nature and the supernatural on which modern "political ontology" ultimately rests.

\section{The Politics of Paradox}

If, as I have argued, the modern redefines metaphysics as the onto-theological sciences of transcendental ontology, then the postmodern marks not so much an alternative to this project as an aporetic extension of it. But there is an alternative modernity that builds on the metaphysical realism inaugurated by Plato and further developed by the Neo-Platonist Church Fathers and Doctors in both the Greek East and the Latin West. The triple current of participation, analogy, and universalism flows through the work of Meister Eckhart, Nicolas of Cusa, the Cambridge Platonists, the Neapolitan and the Scottish Enlightenment to the post-secular metaphysics in the work of J. G. Hamann, Jacobi, and Schelling, who reach back beyond Kant and Hegel to renew the tradition of metaphysical realism. ${ }^{37}$ Common

36. Alain Badiou, Being and Event, trans. Oliver Feltham (London: Continuum, 2005).

37. John Milbank, "Knowledge: The Theological Critique of Philosophy in Hamann and Jacobi," in Radical Orthodoxy, pp. 21-37; John R. Betz, After Enlightenment: The 
to these and other modern figures is a refusal to accept absolute finite limits on the cognoscibility of the infinite-without however returning to the transcendentalism of Cartesian innate ideas in the mind and the dualistic separation of the knowing subject from the known object.

Knowing infinity is also a key theme of the contemporary revival of metaphysics associated with speculative materialism. Knowledge of the infinite is no longer confined to blind faith or pure reason but intelligible to both the senses and the mind because it is mediated in language and appearances. Linked to this move beyond the nineteenth-century secretly collusive opposition of rationalism and fideism (e.g., Kant) is an overcoming of twentieth-century agnosticism that had sought to chart a third way between naturalism and speculation. ${ }^{38}$ Similarly, the renaissance of metaphysical and theological ethics shifts the focus from abstract, general being to the singularity of each person and the universality of truth beyond power or culture. ${ }^{39}$ Truth so configured is perennially invariant and at the same time reflected in ephemeral, material things. As such, truth is both universal and particular, which coincide in the singular.

Thus it is not so much the case that we are seeing a "return of metaphysics," as if the metaphysical had ever gone away. On the contrary, the renewed concern with questions of truth and universality beyond both empirical validity or logical coherence resonates strongly with Plato's realist metaphysics. Here the notion of paradox is key. Philosophically, the logic of paradox concerns the realm of real relations and the transcendent good, which infuses all things with (a desire for) goodness in which each being can share. ${ }^{40}$ In a quest for true knowledge that exceeds mere opinion (doxa), Socrates opposes the sophists on the grounds that they reduce their speeches to commodities, which they either sell to the highest bidder in the marketplace of ideas (as Boris Groyse has remarked) ${ }^{41}$ or which they use

Post-Secular Vision of J. G. Hamann (Oxford: Wiley-Blackwell, 2009); John Laughland, Schelling versus Hegel: From German Idealism to Christian Metaphysics (Aldershot: Ashgate, 2007).

38. Quentin Meillassoux, Après la finitude: essai sur la nécessité de la contingence (Paris: Seuil, 2006).

39. Robert Spaemann, Personen: Versuche über den Unterschied zwischen 'etwas' und 'jemand' (Stuttgart: Klett-Cotta, 1998); Alain Badiou, Saint Paul: La fondation de l'universalisme (Paris: P.U.F., 1998).

40. Plato, The Republic 510b, 511b, 517b-c, 519c-d, 526e; Theaetetus 206c-208b; The Sophist 259e, 263e-264a.

41. Boris Groys, The Communist Postscript, trans. Thomas Ford (London: Verso, 2010), ch. 1. 
in order to manipulate others to their own ends. By contrast, to uncover the paradoxical nature of speech is for Socrates to disclose the reality of the transcendent true, good, and beautiful, which are present in all forms and all things. This presence is mediated to the human mind via both language and ritual. The depth and mysteriousness of the universe warrants the use of myths, metaphors, and analogies. That is why Socrates eschews contradiction-free, coherent, and logically valid argument in favor of paradox that fuses logos with mythos. ${ }^{42}$

The language of myth and the practice of religious ritual provide human experience of the divine realm of the transcendent forms that direct the immanent realm of politics to the true, the good, and the beautiful. Crucially, the finality of politics is neither about managing impersonal, natural necessities or a will to power that is variously more individual or more collective. Much rather, the teleology of the political is the harmonious ordering of the soul (psuche), the household (oikos), and the city (polis) according to the standards of kalon k'agathon, which fuses goodness with beauty and truth. ${ }^{43}$ Cicero makes the same argument about the intertwining of human culture and the natural world: "The bond of human community and association... is reason and speech, which... reconcile men to one another and join them in a kind of natural partnership [naturali quadam societate]." 44

In short, metaphysical realism suggests that there is no pre-political "state of nature" that requires a social contract (as for Locke, Hobbes, Rousseau, Kant, or Rawls). Man really is a social, political animal—embedded in associative bonds of family and community that are not the product of human artifice against the forces of unalterable nature but instead reflect the paradox of transcendent immanence and immanent transcendence.

Politically, the logic of paradox concerns the guidance of the soul, the household, and the city. The soul and the household require education and training by the good city in the same measure as the good city needs to be governed by honorable people and communities. This is connected with the idea of a virtuous guiding elite, the guardians of the republic, who guide the people just as they are guided by the reality of the forms that are beyond their control or manipulation. Indeed, for Plato the forms are not

42. Catherine Pickstock, After Writing: On the Liturgical Consummation of Philosophy (Oxford: Blackwell, 1998), pp. 3-46.

43. Plato, Gorgias 464b and 465a-e; The Republic 510b, 511b-c.

44. Cicero, De Officiis, book I, ch. XVI. 
Cartesian innate ideas in the human mind but embodied in really existing things and as such objects of reason, language, and ritual. Knowledge of the true, the good, and the beautiful is a matter of personal reflection and political engagement. It requires private contemplation, public discussion, and communal practice such as liturgy and sacrifice. The exercise of practical wisdom (phronesis) in pursuit of a just political order balances the democratic demand for the equal right of all with universal standards of the true and the good. As such, the perennial realism of Platonist metaphysics rejects the empty universalism that underpins the liberal fusion of political absolutism with moral relativism under the guise of individual freedom of choice and the tyranny of mass opinion.

Similarly, for Cicero the republic reflects a wider cosmic order in which reciprocal ties are mutually augmenting. The principle that underpins the creation of the public realm (res publica) is itself "a kind of natural coming-together (congregatio) of men" 45 - through bonds of friendship and other forms of human association that bind together the rights and shared interests of citizens within cities and commonwealths. Cicero links friendship to the "will of the people" and common consent, which provides mediation between those who govern and those who are governed. This account informs the ancient argument in favor of "mixed constitutions" that blend elements of monarchy, aristocracy, and democracy. Balancing the power of the "sovereign one" and the "sovereign many" with the power of the "mediating few" (i.e., virtuous guiding elites) reinforces the rule of the personal. Crucially, the metaphysical politics and ethics of virtue overcomes the abstract, vacuous generality of being, which is the mark of modern "political ontology," in the direction of the human person that mirrors its divine source.

Economically and socially, the logic of paradox upholds real relations by accentuating social bonds of reciprocity and solidarity that are based on universal sympathy and are more mutualist in outlook, as Aristotle suggested. By contrast with the modern disembedding of the economic from the social, Aristotle's metaphysics models the economy (oikonomia) on the example of the household (oikos). In this manner, the economic is embedded in the social and constitutes a "nested," interlocking union of personal and professional associations. In ways that complement Plato's guardians who uphold the Good, Aristotle emphasizes the goods that are internal to 
specific activities and accordingly accentuates the practice of virtue in our private as well as our public life. As the middle way between extremes, virtues mediate among competitive and potentially conflictual relations, directing them away from mutually diminishing vice toward standards of excellence and the common good. Just as courage is the middle way between recklessness and cowardice, so too justice marks a harmonious ordering of relations beyond selfishness and altruism. By linking citizens to one another in terms of mutual rights and reciprocal duties, justice is the "bond of men in states." ${ }^{46}$ But since nature and human society are characterized by identity and difference (or commonality and unity) that threaten to cancel out each other, the polis requires a governing principle that can tie the universal to the particular: "[t]hat is why the principle of reciprocity, as I have already remarked in the Ethics, is the salvation of states. Even among freemen and equals this is a principle which must be maintained, for they cannot all rule together but must change at the end of a year or some other period of time or in some order of succession." ${ }^{27}$

Thus, the logic of paradox views groups and associations as more primary than the individual and the collective. Across different societies and cultures, social bonds and intermediary institutions have traditionally been more fundamental than either constitutional-legal rights or economic-contractual ties. The activities of autonomous and democratically self-governing groups and associations are for social purposes and reasons of mutual recognition that - paradoxically - can serve both private and public interests. They do so by helping to bring about conditions for the "good life" that all can pursue.

The focus on paradox in the ancient tradition of metaphysical realism offers conceptual resources and appropriate practices to challenge the post-metaphysical direction of political ontology. It opens up the space for combining elements of "civil economy" with aspects of associative democracy in order to develop the idea of a "civil state" and a moral market that can democratize both politics and the economy by re-embedding them in the social relations of civil society. Common to the traditions of "civil economy" and associative democracy are three closely connected arguments. ${ }^{48}$ First of all, the modern emphasis on the individual and the

46. Aristotle, Politics I, 2, 1253a37-38.

47. Aristotle, Politics II, 2, 1261a30-35.

48. Polanyi, The Great Transformation; Paul Hirst and Veit-Michael Bader, eds., Associative Democracy: The Real Third Way (London: Frank Cass, 2001); Luigino Bruni 
collective neglects the importance of autonomous, democratically selfgoverning groups and associations that mediate between the citizen, the state, and the market. Second, the active participation of groups and associations is indispensable to a properly functioning democracy and market economy. Third, the social bonds and civic virtues that provide the glue for civil society are needed to make constitutional-legal rights and economiccontractual ties work. The fundamental point is that the practice of virtue is not limited to predominantly non-instrumental relationships such as family, friends, or activity in the "voluntary sector" but extends to the largely instrumental relations in the polity and the economy.

The shared intellectual roots of this approach go back to nineteethand early twentieth-century critiques of liberalism and alternative theories of pluralism that draw on the tradition of realist metaphysics. ${ }^{49}$ Broadly speaking, liberalism combines some of the worst aspects of individualism and collectivism. Laissez-faire capitalism reduces not only goods and labor but also land and social relations to commodities that can be freely exchanged according to their monetary market value. Bound up with this is the primacy of subjective, individual rights over mutual duties and reciprocal responsibilities within groups and associations. Since unbridled commercial exchange requires a force to eliminate resistance to it and compensate for any failures (or "negative externalities"), laissez-faire capitalism combines the "free" market with the strong state. For example, statist welfare that is run centrally and based on uniform standards and targets is subservient to capitalism because it compensates for market failure but does not change the fundamental relation between capital owners and wage laborers. ${ }^{50}$ As such, much of economic and political liberalism combines market atomism with state corporatism.

The pluralist alternative is, first of all, to reject both capitalist markets and collectivist states in favor of voluntary and democratically selfgoverning associations that cut across the false liberal divide between the purely private sphere and the exclusively public sector by cooperating with state authorities and market actors in the delivery of services such

and Stefano Zamagni, Civil Economy: Efficiency, Equity, Public Happiness (Bern: Peter Lang, 2007).

49. Among the key thinkers are Pierre-Joseph Proudhon, Robert Owen, George Jacob Holyoake, John Neville Figgis, Harold J. Laski, and G. D. H. Cole. See Paul Hirst, ed., The Pluralist Theory of the State: Selected Writings of G.D.H. Cole, J. N. Figgis and H. J. Laski (London: Routledge, 1989).

50. Polanyi, The Great Transformation, pp. 140-71. 
as health, education, or welfare. As Paul Hirst puts it, this approach "aims to strengthen government in and through civil society; thus civil society takes on many of the attributes of the public sphere." ${ }^{51}$ Second, political authority is more effective, efficient, and democratic if it is decentralized in line with the principle of subsidiarity, i.e., devolving power to the most appropriate level that promotes democratic participation and protects the dignity of citizens. By contrast with centralization and exclusive central state power, pluralism shifts the emphasis to the cooperation of different actors and a balance of power between interests within institutions. Third, the economy is not run according to the logic of "free-market" competition or bureaucratic state planning but instead along more mutualist lines, where firms are governed jointly by investors, managers, and workers, and financial investment includes a social purpose. Thus, the work of Polanyi can extend Hirst's idea of "associative democracy" by democratizing the market and mutualizing the economy. Maurice Glasman puts this well:

The paradoxical idea here is that the greater the diversity of democratic institutions that entangle capitalism in relationships based on knowledge and mutuality, the better the chances of releasing the energies of the workforce and generating growth. The more workers have power, the more efficient it is; the more that local communities engage in banking, the more sustainable the returns. This is about breaking the logic of short-term returns, which undermines long-term development. I think that associative democracy has therefore to be complemented by a much more explicit notion of the possibilities and threats of capitalism, the logic of the market, and how to domesticate it. ${ }^{52}$

The idea of more mutuals or cooperatives instead of state-owned enterprise or private cartels/monopolies provides the link to Bruni's and Zamagni's "civil economy." 53 Indeed, this notion is based on the argument that the market can use resources efficiently and promote the common good effectively only if it is disciplined by the habit of practicing reciprocal

51. Paul Hirst, From Statism to Pluralism: Democracy, Civil Society and Global Politics (London: Routledge, 1997), p. 32.

52. Maurice Glasman, "How to Combine Hirst and Polanyi to Create a Strong Argument for an Embedded and Democratic Economy," in Andrea Westall, ed., Revisiting Associative Democracy (London: Lawrence \& Wishart, 2011), pp. 64-70; here, p. 69.

53. The origins of the notion of "civil economy" go back to Renaissance humanism and the Neapolitan Enlightenment. John Robertson, The Case for the Enlightenment: Scotland and Naples, 1680-1760 (Cambridge: Cambridge UP, 2005), pp. 201-405. 
and mutual virtues. If, by contrast, the market is equated with pure instrumentality, then human and social relationships are reduced to means that maximize individual utility and private profit. Since the state enforces rights and contracts, it is an integral part of the liberal market logic. Here Bruni and Zamagni show that the principle of contract that underpins the modern market needs to be supplemented by the principle of reciprocity because otherwise self-interest overrides and ultimately undermines the common good - not the sum total of individuals goods and services but rather the good of real relationships and the worth of each and everyone in terms of their specific embeddedness in the complex webs of trust and reciprocity. Connected with this is the tendency of modern markets to "financialize the real economy," a process that also cuts off production and trade from the common good that enhances rather than diminishes real utility and happiness. Thus, the politics of paradox emphasizes the need to re-embed both the state and the market within a wider network of social relations that are governed by reciprocal virtues such as justice, solidarity, fraternity, and responsibility. Such a politics is more economically egalitarian than the social-democratic left and more committed to a culture of virtue than the neo-liberal right.

\section{Conclusion}

This essay has argued that modern "political ontology" needs to be overcome in the direction of a metaphysical politics. Philosophically, modernity and postmodernity are characterized by the invention and extension of the onto-theological science of transcendental ontology. The work of Scotus, Ockham, Machiavelli, and Suárez bequeathed three currents-possibilism, transcendentalism, and absolutism - that flow through figures such as Wolff and Clauberg to Kant, who consummates the complete critical turn of modern ontology into epistemology, with the dualism of the knowing subject and the known object constitutively unresolved.

Politically, all the modern binary opposites such as state versus market or left versus right are grounded in a modern logic of dualism - the aporia between unalterable nature (the originally violent "state of nature") and human artifice (the social contract). This logic of dualism reduces real relations among people or between humanity and the natural world to nominal connections that take the form of constitutional-legal rights or economiccontractual ties. Such nominal connections undermine the social bonds of reciprocity and mutuality and the intermediary institutions of civil society upon which vibrant democracies and market economies depend. 
By contrast, the alternative logic of paradox eschews the dualistic categories such as the "left" linked to the central state versus the "right" allied with the free market in favor of a "radical center." This "radical center" is the metaphysical realm of real relations and the common good in which all can share. Metaphysics properly configured translates into social bonds of reciprocal trust and mutual giving underpinning diverse forms of human association. Such bonds are - paradoxically — more particular than commercial ties based on abstract standards of monetary value and also more universal than the supposedly inalienable individual rights to life or to property that can be alienated by the state or the market.

By combining a focus on civic and ethical limits to both central state and free market power with an emphasis on greater economic equality and political participation, the logic of paradox is more progressive than left-wing centralized statism and more conservative than right-wing, "free-market" liberalism. As such, it outflanks the "old left" and the "new right" in the direction of a paradoxical politics. The notion of paradox is neither a logical contradiction nor a residually transcendental dialectic but instead that which exceeds opinion in the direction of true knowledge and wisdom - an immanent openness and outlook to the transcendent truth and beauty of the supernatural good in God. 